\title{
ハードマテリアルの最近の開発動向 および今後の課題*
}

Recent Development Trend and Future Challenge of Hard Material

\section{$\underset{\text { Akira OSADA }}{\text { 長田** }}$}

Key words hard material, cutting tool, cermet, CVD, PVD, PCD, PCBN

\section{1. は じめに}

超硬合金，サーメット，超高圧焼結体等のハードマテリ アル（硬質材料）は切削工具, 耐摩耗工具・部品, 鉱山土 木工具等に使用され，用途に応じ最適材料が使い分けられ ている。ここ数年, 資源・環境・エネルギー問題は世界的 な課題としてその重要性抢よび緊急性が一段と高まってお り, ハードマテリアルの開発にも大きな影響を及ぼしてい る。ハードマテリアルとして最も使用量の多い超硬合金の 主成分は炭化タングステン（WC）であり，原料である夕 ングステン (W) の生産・供給の約 9 割は中国に依存して いるため, その安定確保は業界における喫緊の課題であ る。このため, W の使用量低減技術および代替材料の開 発は，2007 年度より実施の経済産業省・NEDO（(独）新 エネルギー・産業技術総合開発機構）の「希少金属代替材 料開発プロジェクト」にも採択され国家プロジェクトとし ての取り組みが行われている。

一方，ハードマテリアルの使用用途の 7 割以上を占める のは切削工具である. 切削加工はものづくりに欠かせぬプ ロセスであり, 近年では高速・高能率加工や高精度加工へ の取り組みが従来にも増して精力的に行われている。 ま た, 材料の高強度化, 金型材の直彫り加工, 鉛フリー化 等, 被削材は難削化の傾向にある. これらの市場ニーズに 応え, 世界的な課題を解決していくため, 先進的なハード マテリアルの開発やそれを応用した新しい切削工具の開発 がますます重要になってきている。

ここでは切削工具用を中心にハードマテリアルの概要を まとめるとともに, 最近の研究開発動向や今後の課題につ

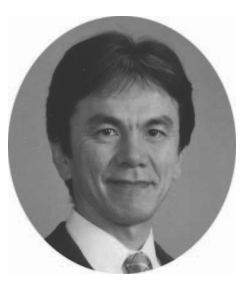

*原稿受付 平成 22 年 9 月 17 日

意マテリアル株式会社中央研究所薄膜材料研 究部（茨城県那珂市向山 1002-14）

長田 晃

1985 年東京大学工学部金属工学科卒業. 工学博 士. 1985 年三菱金属(株) [現：三菱マテリアル (株) ] 入社. 中央研究所薄膜材料研究部部長. CVD 法㧍よびPVD 法を利用した薄膜材料抒よ び各種硬質材料の研究開発に従事.
いて展望する。

\section{2. 切削工具市場とハードマテリアル}

切削工具の世界市場は 2000 年代半ばにおいて年間約 100 億ドルの規模と想定され，年率 5\% 程度で成長し，北 米, 欧洲，日本を主としたアジア地区がそれぞれ 3 割程度 を占める状況であった ${ }^{1)}$. その後, 世界同時不況の影響を 大きく受けたが，現在の総市場は不況前の規模に戻りつつ あると思われる。しかしながら, その市場構成は中国やイ ンド等の新興国市場の急速な拡大等を背景に大きく変化し てきている.これら市場の変化は, 今後のハードマテリアル の研究開発にも少なからず影響を及ぼすものと思われる。

切削工具用のハードマテリアルには，単結晶や焼結体の ダイヤモンド, $\mathrm{cBN}$ (立方晶窒化ほう素) 焼結体，アルミ ナ $\left(\mathrm{Al}_{2} \mathrm{O}_{3}\right)$ 系や窒化珪素 $\left(\mathrm{Si}_{3} \mathrm{~N}_{4}\right)$ 系のセラミックス, 炭 窒化チタン（TiCN）基サーメットや WC 基超硬合金等が 用途に応じ使用されている。これらハードマテリアルに求 められる特性として特に硬さと勒性が重要であるが，一般 に硬さと勒性は相反する特性であるため, 図 1 の概念図 に示されるように各材料は図中右下がりの線上に分布して いる。したがって開発の目標は，材料特性を図 1 の右上の

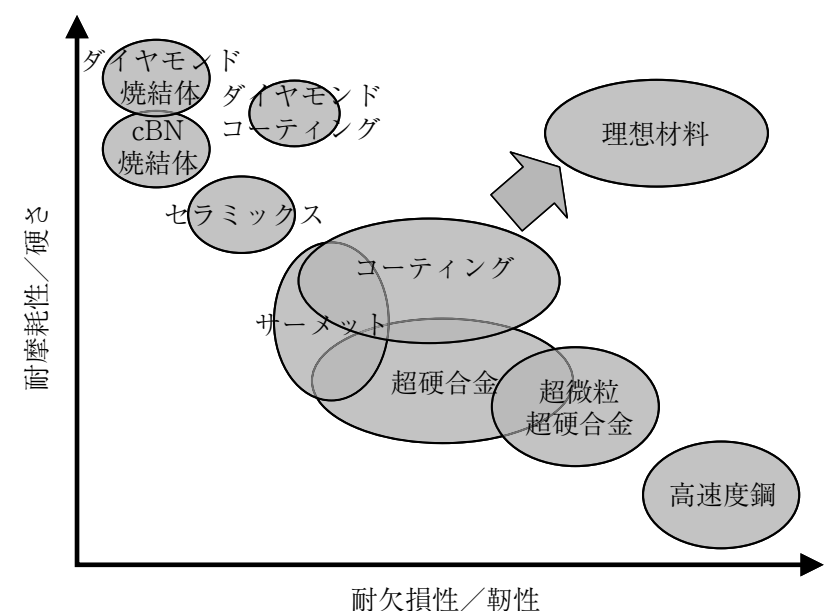

図1 各種ハードマテリアルの位置付け 


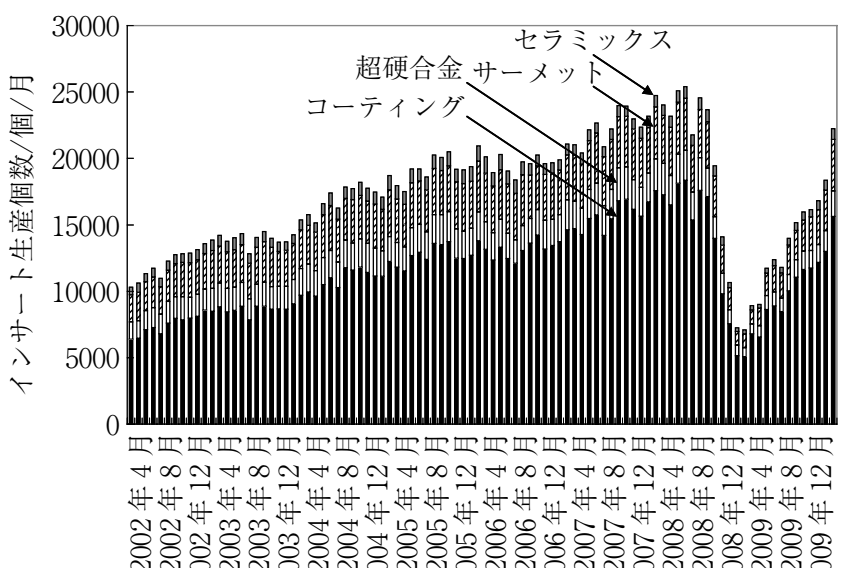

年月

図2

各種ハードマテリアルの位置付け

方向へと向上させることである，図 2 に国内に抢けるイ ンサート生産量の材料別推移（国内）を示す ${ }^{2)}$. 総量は世 界同時不況の影響で大きく変動しているが, 材料別の比率 を見るとコーティング材料の伸びが著しく, 最近では 70\%を大きく超えている。これは，表面のハードコーテ イングにより勒性低下なしに耐摩耗性を大幅に向上できる からである。このため超硬合金をはじめサーメットや cBN 焼結体など，さまざまなハードマテリアルヘコーテ イングの適用が進んでいる。

被削材や加工形態の変化・進展に伴い重要性が高まって いるハードマテリアルとしてダイヤモンドや cBN 焼結体 が挙げられる。自動車や航空機の軽量化のためアルミニウ ム合金に加え CFRP (Carbon Fiber Reinforced Plastics : 炭素瀻維強化プラスチック）の使用量急伸が予想される が，これら非鉄系材料の加工にはダイヤモンド焼結体やダ イヤモンドコーティングが久かせない，また，焼入れ鋼の 加工では研削加工の切削化が進んでおり鉄系の難削材加工 や高精度加工等に最適な材料として $\mathrm{cBN}$ 焼結体の需要も 今後大きな伸びが期待される.

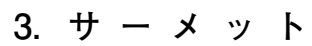

\section{1 超硬合金代替材料としてのサーメット}

超硬合金は硬さと勒性や熱衝撃性等をバランスよく兼ね 備えており，1920 年代に開発・実用化されて以降, 各種 のハードマテリアルが開発された後も, その汎用性を上回 るものは現れていない．しかしながら，冒頭で述べたよう にW の使用量低減は喫緊の課題であり, 代替材料として 最も期待される材料の一つがサーメットである.

サーメットは, 主成分である硬質相が炭化チタン (TiC) や TiCN からなりこれらをニッケル $(\mathrm{Ni})$ やコバ ルト（Co）等の金属で結合した材料で, 一般的に超硬合 金と比へ耐摩耗性に優れるものの耐欠損性に劣る。このた め一般に, 比較的負荷の低い鋼の仕上げ旋削加工等に使用 されている。

\section{2 サーメットの最近の開発動向}

超硬合金と比ベサーメットは耐欠損性に劣るが，その主 な原因の一つとして熱衝撃に弱く熱亀裂が発生しやすいこ とが挙げられる。このため, 刃先に高い熱的抢よび機械的 負荷がかかる切削, 例えば送りや切込み量の多い粗加工や 湿式加工, ミーリング加工等では切刃に熱亀裂やチッピン グが発生しやすくサーメットの使用は困難である。最近の 開発事例として, 熱亀裂の発生と進展を抑制し耐欠損性を 向上させたサーメットがあるが，ここでは硬質相を結合す る金属相を特殊合金化することで熱伝導性を向上させると ともに硬質相との結合力を高め破壊強度を向上させてい る。また，合金粒度と組織を最適化することで従来と比べ 熱亀裂が進展しにくい構造にしている. 冒頭で紹介した 「希少金属代替材料開発プロジェクト」に扔いてもサーメ ットの破壊勒性值と熱伝導率の向上を目指し新規固溶体粉 末の使用による硬質相構造の均質化や高熱伝導相を効果的 に残留させる等の取り組みが行われている3.

代替材料開発には, サーメットそのものの開発に加えコ ーティングの開発も重要であり, 成膜温度の関係で現在は サーメットに適用されていない化学蒸着 (CVD : Chemical Vapor Deposition）法による $\mathrm{Al}_{2} \mathrm{O}_{3}$ を被覆可能とする技術 の開発が必要である。ハードコーティングとしての $\mathrm{Al}_{2} \mathrm{O}_{3}$ は一般的には CVD 法により $1000^{\circ} \mathrm{C}$ 以上の高温で成膜され るが，サーメットを基体とした場合は基体成分の皮膜中へ の拡散等により皮膜，基体共に変質・劣化する。このた め, 低温化のためにレーザーCVD 法を用いた $\mathrm{Al}_{2} \mathrm{O}_{3}$ 成膜 技術の開発が進められている3 ${ }^{34)}$.

\section{4. セラミックコーティング}

\section{1 ハードマテリアル用のコーティング技術}

現在, 切削工具用コーティングの成膜方法として実用化 されているのは, CVD 法と物理蒸着 (PVD: Physical Vapor Deposition）法の 2 種類である. CVD 法によるコ

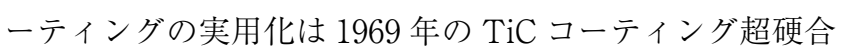
金の発売に始まり,その後, 窒化チタン ( TiN), $\mathrm{TiCN}_{1} \mathrm{Al}_{2} \mathrm{O}_{3}$ 等のコーティング技術が開発された.また，PVD 法による コーティングとしては 1980 年代初めに TiN の単層コーテ イングが発売され，その後 1990 年代に, 窒化チタンアル ミニウム $((\mathrm{Ti}, \mathrm{Al}) \mathrm{N})$ をはじめとする多元系の窒化物コ ーティングが実用化されている，現在では，インサート， ドリル・エンドミルなど各種工具へ幅広く適用され, 切削 工具用ハードマテリアルの主要材料となっている.

\subsection{CVD 法によるコーティングの開発動向}

\subsubsection{TiCN 成膜技術}

図 3 に切削工具用コーティング技術の変遷を示す. CVD 法に抢いては 1990 年代初め以降に MT (Moderate Temperature：中温） CVD 法による $\mathrm{TiCN}$ 成膜技術とそ の関連技術の開発・実用化が急速に進んだ．MTCVD 法 による TiCN の成膜には原料ガスとしてアセトニトリル $\left(\mathrm{CH}_{3} \mathrm{CN}\right)$ などの有機 $\mathrm{CN}$ 化合物が使用され, メタン 


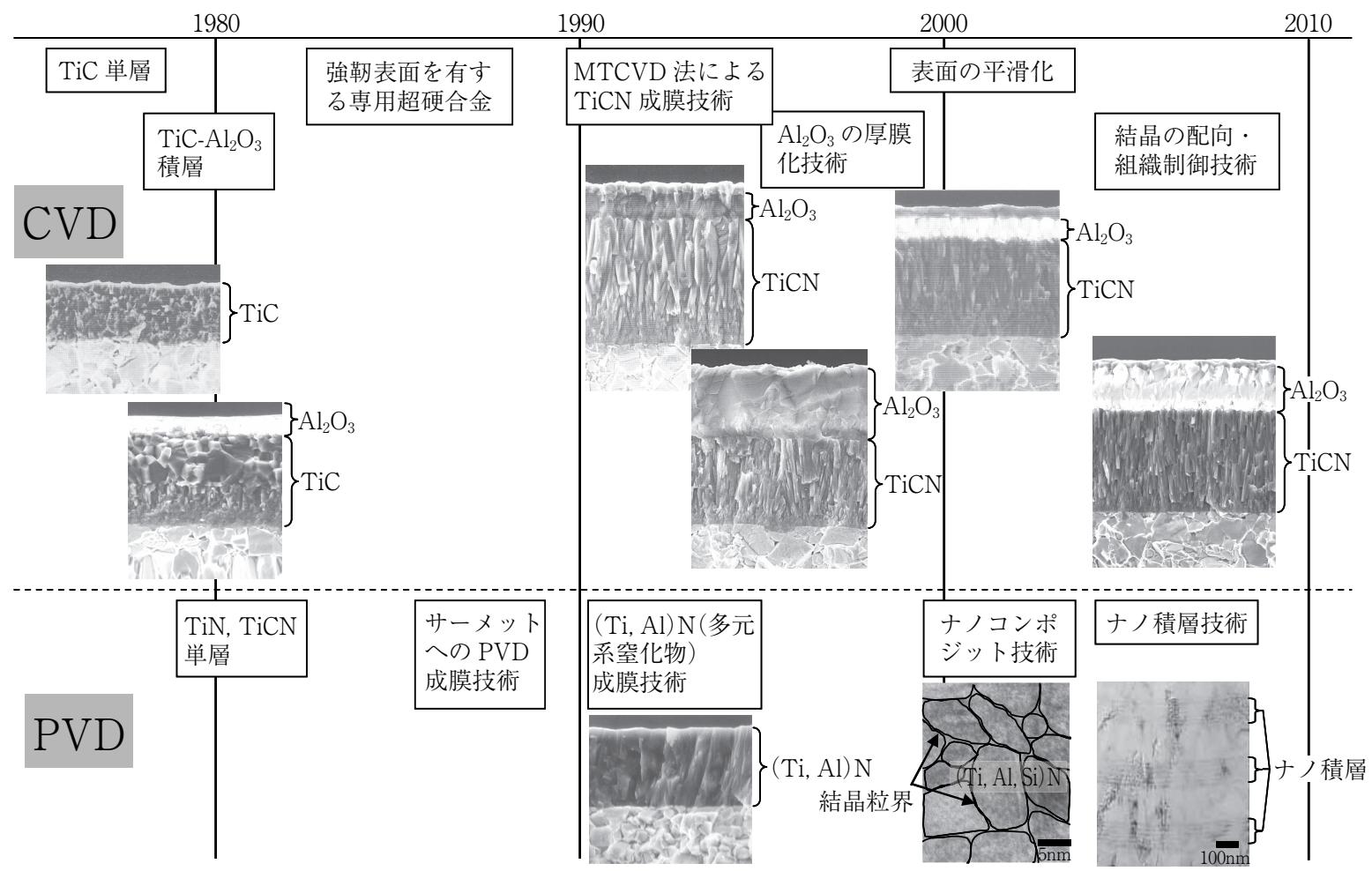

図３＼cjkstart切削工具用コーティング技術の変遷

$\left(\mathrm{CH}_{4}\right)$ や窒素 $\left(\mathrm{N}_{2}\right)$ などを使用する従来の熱 CVD 法 (HT (High Temperature) CVD 法) と比べ比較的低温の 700 900 Cで成膜が可能である. MTCVD 法による TiCN の断面組織は, 図 3 右上側に見られるように柱状あるいは 纎維状を呈する。 また, HTCVD 法と比べ比較的低温で成 膜されることから基体である超硬合金の変質が少なく, 皮 膜に発生する引張残留応力も低くなる。 これら特徵的な組 織形態と基体の変質抑制, 引張残留応力の低減等による効 果で基体および皮膜の強度が著しく改善された。このため MTCVD 法による TiCN の実用化以降, 皮膜厚さは大幅 に増加しており, 最近では $20 \mu \mathrm{m}$ を超えるものも現れて いる. TiCNの改良はその後も進められ, 組織の微細化や 積層化等の各種構造制御によりさらなる性能向上が図られ てきている。

\subsection{2 $\mathrm{Al}_{2} \mathrm{O}_{3}$ 成膜技術}

$\mathrm{Al}_{2} \mathrm{O}_{3}$ には結晶構造の異なる多型が存在するが, 切削工 具用としては $\alpha-\mathrm{Al}_{2} \mathrm{O}_{3}$ と $\kappa-\mathrm{Al}_{2} \mathrm{O}_{3}$ の 2 種類が実用化され 用途に応じて使い分けられている。 $\alpha-\mathrm{Al}_{2} \mathrm{O}_{3}$ は高温での安 定相であり, 高温での硬さや耐酸化性, 化学的安定性など に優れるため, 切削工具用としては一般的には $\alpha-\mathrm{Al}_{2} \mathrm{O}_{3}$ が有効である。しかしながら応用の際には， TiC や TiCN 等の下部層との付着強度を得にくく, 成膜時に結晶が粗粒 化しやすいといった量産上の課題がある。これら課題の解 決策として, $\mathrm{Al}_{2} \mathrm{O}_{3}$ と下部層との界面には数 10 数 100 $\mathrm{nm}$ 程度の各種の中間層が使用されている。中間層によ る, 付着強度の改善にともない $\mathrm{TiCN}$ 同様 $\mathrm{Al}_{2} \mathrm{O}_{3}$ において も厚膜化が進んでいる。最近では，中間層物質の開発だけ
でなく中間層の結晶組織や多層構造, 成長方向での組成変 化等, ナノオーダーの領域での各種制御技術の開発が進め られている。 これは $\mathrm{Al}_{2} \mathrm{O}_{3}$ 下部の中間層が界面の付着強 度だけでなく $\mathrm{Al}_{2} \mathrm{O}_{3}$ の結晶型や結晶方位, 微細組織等に も大きな影響を及ぼすためである. $\mathrm{Al}_{2} \mathrm{O}_{3}$ の切削性能は結 晶方位や微細組織により大きく変化することが確認されて おり ${ }^{5) 6)}$, これらの制御技術は今後の開発の最重要課題の 一つである。

\subsection{PVD 法によるコーティングの開発動向}

$\mathrm{PVD}$ 法は成膜温度が室温から $500^{\circ} \mathrm{C}$ 程度と CVD 法と比 べ比較的低温で成膜でき，基体に与える影響が少ないこと から超硬合金に限らず高速度鋼やサーメット，セラミック ス， cBN 焼結体などさまざまなハードマテリアルへ適用 が可能である。その汎用性の広さから, 特にドリルやエン ドミル等のソリッド工具を中心に年々使用量が増加してい る. 切削工具用には, 高いイオン化率が得られ蒸気圧の異 なる 2 種以上の金属を同時に加熱蒸発させることが可能な AIP (Arc Ion Plating) 法が用いられる場合が多く，（Ti, Al) N も主として AIP 法により成膜される. 2000 年代に は, ( $\mathrm{Ti}, \mathrm{Al}) \mathrm{N}$ の硬さや耐酸化性をさらに上げることを目 的に, $\mathrm{Ti}, \mathrm{Al}$ に加え $\mathrm{Si}$ や $\mathrm{Cr}$ を添加することや $\mathrm{Ti}, \mathrm{Al}$ のい ずれかを $\mathrm{Si}$ や Cr で置き換えた皮膜などの開発・実用化が 進んだ。眓 3 右下側に示すように, 最近ではコーティング 物質の開発に加え皮膜の微細組織構造や積層構造をナノオ ーダーで制御することによる特性向上についてもさまざま な開発が行われている。

AIP 法の欠点として, アーク放電の際にターゲットか 
ら飛び出る溶融金属粒子が未反応のまま粗大粒子（マクロ パーティクル）として皮膜内部に取り达まれたり，表面に 付着したりすることが挙げられる。このため，溶融金属粒 子が基体に到達しないようにする工夫や溶融金属粒子の発 生自体を抑える等の改善が行われている。また， AIP 法 に比ベマクロパーティクルの発生が少ないマグネトロンス パッタリング法による皮膜開発も進められ，スパッタリン グ法の欠点であったイオン化率の低さを改善したアンバラ ンストマグネトロンスパッタ（UBMS）法の開発や付着強 度の改善等により工具用途での実用化が進んでいる。最近 では高出力パルス電源により, さらなるイオン化率の向上 を目指した HIPIMS (HIgh Power Impulse Magnetron Sputtering）法による開発も盛んに行われている。スパッ タリング法では， $\mathrm{Al}_{2} \mathrm{O}_{3}$ 等の各種酸化物や嗍化物など絶縁 性の皮膜も比較的容易に成膜可能であり，これらの皮膜も 次第に実用化されていくものと思われる.

\section{5. ダイヤモンドおよび cBN 系ハードマテリアル}

\section{1 ダイヤモンド焼結体（PCD）およびダイヤモンド コーティング}

切削工具としてダイヤモンドが有効であるのは，主とし てアルミニウムや銅合金などの非鉄金属材料, CFRP や MMC（Metal Matrix Composite）などの複合材料の加工 である。とりわけアルミニウム合金やCFRP は，車両軽 量化のための代替材料や今後の成長産業である航空機用の 材料として，その使用量の大幅な増加が見込まれる。

ダイヤモンド焼結体（PCD : Poly Crystalline Diamond） は，これら非鉄金属や非金属材料の切削で優れた耐摩耗性 を示し，これら材料の高精度，高能率加工に活用されてい る. 最近の開発例として, バインダーを含まない微粒のダ イヤモンドのみからなる多結晶体があり ${ }^{7)}$, 単結晶を凌駕 する硬さや強度を有するため, 次世代の高性能切削工具と して有望である。別の取り組みとして $\mathrm{MgCO}_{3}$ 等の非金属 助剤を利用した焼結法を利用することで硬さや耐熱性を向 上させた焼結体も開発されており ${ }^{8)}$, 難削性の高い $\mathrm{MMC}$ 材の加工での有効性が確認されている．両プロセスとも実 用化の進展に向けた量産課題の早期解決が期待される. PCD を切削工具として使用する場合は，ドリルやエンド ミル等の複雑形状の切刃に PCD をいかにして適用するか が最大の課題となる。つまり，複雑形状の切刃に応じた $\mathrm{PCD}$ 素材の焼結技術や研磨技術等の生産技術開発が重要 である。

$\mathrm{PCD}$ の適用が難しい複雑形状の切刃を有する切削工具 においては，ダイヤモンドコーティングが有効となる。 ダ イヤモンドコーティングは切削工具としての実用化から 20 年程度が経つが, 切刃の信頼性やコストパフォーマン スの点で十分な評価が得られておらず，その使用範囲は限 定的である。今後の適用範囲拡大に向けた開発課題として は，上記 PCD との競合という観点で，より一層の信頼性 向上，具体的には皮膜剥離やチッピング等の異常損傷の防
止が第一に挙げられる。このためには付着強度の改善や結 晶粒の粗大化抑制による皮膜表面の平滑化などが必要であ る。また，再研磨性という点では使用後の除膜および再コ ーティング技術の開発も重要と考えられる.

\section{$5.2 \mathrm{cBN}$ 焼結体（PCBN）}

$\mathrm{cBN}$ 焼結体 (PCBN) は，ダイヤモンドと比べ鉄系材料 との反応性の点で優れた特性を有するため, PCD が適用 できない鉄系の高硬度材や焼結合金等の難削材加工用の八 一ドマテリアルとして，その使用量は年々増加している. 特に，鋳鉄製エンジンブロックや， ギヤ，シャフト，ベア リングなどの焼入れ鋼の切削加工に欠かせぬ材料である.

これら被削材の加工においても高速 · 高能率化や高精度 化は今後も一層進むと考えられ，他のハードマテリアルと 同様に PCBN 工具にもより強勒で高い熱伝導率を有する 材料の開発が望まれる。最近では, $\mathrm{cBN}$ 含有量の増加 (結合材の低減), 構成粒子の微粒化や構成粒子界面の強度 向上等の開発が進められている。また, PCBN 自体の性 能向上とともに，耐熱性や潤滑性向上を目的とした $\mathrm{PCBN}$ へのコーティング技術の開発も重要と考えられる.

\section{6.お わりに}

ハードマテリアルは, 1920 年代の超硬合金の実用化に 始まり 1950 年代のサーメット, 1970 年代のコーティング 超硬合金，窒素含有サーメットの実用化等，80 年以上の 永きにわたり精力的な研究開発が継続的に行われ大きな進 歩を遂げてきた。その間，各種の先進ハードマテリアルが その時々のさまざまな要求に応え課題を解決することで産 業の発展に大きく寄与してきた。しかしながら，希少資源 である原料金属の使用量削減のための代替材料開発，新興 国の急成長や $\mathrm{CO}_{2}$ 排出量規制にともなう市場変化に即し たハードマテリアルの開発等, 現在も多くの課題に直面し ている，今後さらに，先進的なハードマテリアルやプロセ スの開発が行われ実用化が進むことで，これまで以上に産 業の発展に貢献していくことを期待したい.

\section{参 考 文 献}

1) Cutting Tools-World Markets, End-Users \& Competitors : 20052010, DEDALUS CONSULTING, (2005).

2) 超硬工具協会統計.

3）松原秀彰, 山口哲央 : 希少金属代替材料開発プロジェクト, 金 属, 79, 12 (2009) 1081.

4) H. Kadokura, A. Ito, T. Kimura and T. Goto: Moderate Temperature and High-speed Synthesis of $\alpha-\mathrm{Al}_{2} \mathrm{O}_{3}$ Films by Laser Chemical Vapor Deposition Using Nd: YAG Laser, Surf. Coat. Technol., 204 (2010) 2302.

5) A. Osada, E. Nakamura, H. Homma, T. Hayahi and T. Oshika: Wear Mechanism of Thermally Transformed CVD $\mathrm{Al}_{2} \mathrm{O}_{3}$ Layer, Int. J. Refract. Met. Hard Mater., 24 (2006) 387.

6) S. Ruppi : Enhanced Performance of $\alpha-\mathrm{Al}_{2} \mathrm{O}_{3}$ Coatings by Control of Crystal Orientation, Surf. Coat. Technol., 202 (2008) 4257.

7）角谷均, 入舩徹男: 高硬度ナノ多結晶ダイヤモンドの合成と特 徵, NEW DIAMOND, 22, 3 (2006) 6 .

8）赤石實：耐熱ダイヤモンド焼結体の高圧合成，セラミックス, 32, 6 (1997) 461 